\title{
Salvage logging versus natural regeneration post-fire practices in a forest: Soil chemical and microbial aspects
}

\author{
Orit Ginzburg, Yosef Steinberger ${ }^{\star}$ \\ The Mina \& Everard Goodman Faculty of Life Sciences, Bar-Ilan University, Ramat-Gan, Israel; \\ *Corresponding Author: Yosef.Steinberger@biu.ac.il
}

Received 9 October 2011; revised 20 November 2011; accepted 10 December 2011

\begin{abstract}
The increase in forest-wildfire events around the world has revived the old debate regarding the practice of salvage logging and its effectiveness in comparison to the unlogged, natural regeneration of burned forests. Since the logging of burned trees may have undesirable outcomes in soil systems, such as soil compaction and nutrient losses, these changes could further cause disturbances to soil microbial-community activity. The aim of this study was to examine chemical and biological changes in soil under two post-fire practices: salvage logging and unlogged, natural regeneration of burned areas, in the recently burned Byria Forest in Israel. Results indicated that salvage logging had a shortlived effect on soil chemical and biological properties that was confined mostly to the first year after logging. Soil moisture was greatly affected by salvage logging, and drier conditions were found in the logged compared to the unlogged burned areas. Moreover, logging had a negative effect on microbial biomass, with reduced biomass in the logged compared to unlogged areas, which was more evident during the first year after fire. These findings support the recommendations in the literature to postpone postfire practices such as logging or, in turn, to combine the two practices in order to create a mosaic of burned-logged and burned-naturally regenerated areas.
\end{abstract}

Keywords: Microbial Community; Natural Regeneration; Post-Fire Practice; Salvage Logging; Wildfire

\section{INTRODUCTION}

Wildfires are disturbances that occur in forests around the world and affect various aspects of these ecological systems at a variety of spatial and temporal scales. According to climate models, a $30 \%-50 \%$ increase in the occurrence of forest wildfires is predicted over the next century $[1,2]$. This raises issues on proper pre-fire protection and post-fire restoration practices [3-5]. One of these issues is the question of whether to use human intervention in the form of salvage logging or perhaps to rely on the natural regeneration forces of the forest with minimum human intervention [6].

Salvage logging involves the removal of particular trees or stands, mostly for its commercial value, after natural disturbances such as hurricanes or wildfires $[6,7]$. In most burned forests, logging or harvesting is usually the immediate restoration practice, followed by the planting of new trees. This is usually done because burned forests are perceived negatively, either as being damaged or destroyed $[5,8]$, or as being unattractive to the public eye [9]. Moreover, it is assumed that logging slows the buildup of insect-pest populations and reduces fuel loads and the risk of re-occurring wildfire [10,11], as well as increasing the safety of visitors.

Although salvage logging is widespread and supported by some of the above reasonable factors, data that have accumulated in the literature raise the question of the validity of these factors $[12,13]$. Recent studies [14-16] reported that even though logging removes large woody fuels, it may, on the other hand, increase the risk of fire because of the increase of unmerchantable material on the forest floor. Rab [17] and McIver and Starr [10] reported that logging practices resulted in soil compaction and interference to soil chemical or biological functioning. Karr et al. [18] also reported changes in the hydrological regime of logged ecosystems and a diminished capacity of the ecosystem to recover from a second logging disturbance [4]. Logging can cause damage to burned sites, remove structures that are important for ecological functions [19], and may have negative conesquences for many birds, insects, and soil organisms [4]. Beghin et al. [5] reported more sapling regeneration in 
naturally regenerated than logged sites. Therefore, the success of logging as a beneficial practice is questionable.

Currently, there is insufficient information available on the ecological outcomes of salvage logging even though it is widespread [20]. Even less evidence exists on the effect of salvage logging on soil microbial communities $[4,21,22]$. In Israel's pine forests, salvage logging is the first management step after a wildfire [13]. However, the effects of salvage logging on soil microbial communities have yet to be examined and, to the best of our knowledge, this is the first study carried out in this country to do so. Soil microbial communities are key components in maintaining soil function, and knowledge of their responses to disturbance is essential for understanding ecosystem stability and dynamics and, hence, management [23]. As more knowledge is gained, it could be used to develop effective management guidelines and to adequately inform policy decision-makers [20].

The objective of this study was to follow changes in soil microbial-community activity and composition in two different post-fire forest-management practices, logging and natural regeneration (unlogged). Sampling was performed immediately after logging, and monitored for as long as three years post-logging. We hope that this study will assist in planning future forest management after fires in Israel and other countries.

\section{METHODS}

\subsection{Study Site}

The study area was located in the Byria Forest in northern Israel. This area has a typical Mediterranean climate, with mild, rainy winters and hot, dry summers. The mean annual rainfall is $700 \mathrm{~mm}$, with rain falling almost exclusively during the winter months (December-February). The mean maximum daily temperature in the summer season is $30^{\circ} \mathrm{C}$ (August) and in winter (January) it is $9^{\circ} \mathrm{C}$. The topography is hilly, with several steep slopes.

Vegetation at the site is primarily composed of pines (Pinus halepensis and Pinus brutia) and cedars (Cedrus atlantica and Cedrus brevifolia) that were planted over the past 50 years. A wildfire that occurred in summer 2006 consumed about 200 hectares of this mature forest.

The soils are of the pale Rendzina type (Xerorthents), derived from chalk and limestone $\left(\mathrm{CaCO}_{3}: 88 \%\right)$. Soils of this type are considered highly weathered and characterized by relatively low nutrient content $(\mathrm{N}: 0.09 \%$; organic C: $1.14 \%$ ) [24].

The study site presented a rare opportunity for tracking changes under conditions of homogeneity in tree composition, understory litter, slope positions (northfacing), soil characteristics, and proximity to the un- burned forest (control), which had similar characteristics.

\subsection{Experimental Design}

An area of approximately 200 hectares of forest was burned by wildfire in July 2006 . While the understory was completely destroyed during the fire, the trees were either completely or partially burned. An unburned forest area located as far as $300 \mathrm{~m}$ away but exhibiting biogeological and chemical characteristics similar to those of the burned area, served as a control.

Two post-fire practices were used in the burned forest area: salvage logging (B-SL) and natural regeneration practice - unlogged areas (B-UL). Each practice covered 4 plots, each $50 \times 50 \mathrm{~m}$ in size. Until logging, the burned areas were left to recover naturally without any human interference. All of the burned areas prior to logging and after it had similar topographic, geophysical, and chemical soil characteristics. Salvage logging was performed by a private company one year after the wildfire and sampling started just as the treatment ended, in October 2007. Logging involved specialized machinery and mechanical equipment brought into the area through special paths made by the forest workers.

\subsection{Soil Sampling}

Four soil samples were collected and pooled together from each of the four plots assigned to each post-fire practice: salvage logging (B-SL); unlogged (B-UL) and from four unburned control plots (UB). Sampling began in autumn (October) 2007, after logging ended $\left(\mathrm{t}_{0}\right)$, and continued seasonally (autumn, winter, spring, summer) until summer 2010 (about 3 years after logging practice began). Each soil sample was immediately placed in an insulated container and taken to the laboratory. The soil samples were kept in cold storage at $4^{\circ} \mathrm{C}$ until processing. Before biological and chemical analyses, they were sieved (2-mm mesh size) in order to remove root particles and other organic debris.

\subsection{Laboratory Analysis}

The following analyses were performed on each soil sample:

\subsubsection{Soil Moisture}

Soil moisture (SM) was determined gravimetrically as percentage of dry mass by drying the samples to a constant weight at $105^{\circ} \mathrm{C}[25]$.

\subsubsection{Soil Organic Carbon}

Soil organic carbon (OC) content was determined by oxidation with $1 \mathrm{~N}$ potassium dichromate in acidic medium, according to Rowell [26]. 


\subsubsection{Total Soluble Nitrogen (TSN) and Dissolved Organic Carbon (DOC)}

Total Soluble Nitrogen (TSN) and Dissolved Organic Carbon (DOC) were determined by chemical extraction and color reactions using a Skalar autoanalyzer. Dried soil samples were extracted in a 1:10 (w/v) ratio with $0.01 \mathrm{M}$ calcium chloride solution. Total soluble $\mathrm{N}$ : The determination of total $\mathrm{N}$ content was based on the following reaction: a sample was mixed with a borax buffer, excess potassium persulfate solution was added, and the mixture was placed in an ultraviolet digester. Nitrate was determined by the Griess reaction after oxidation of ammonium and reduction of nitrate to nitrite by cadmium copper redactor. The color was measured at 540 nm [27]. Dissolved organic C:A sample was acidified and the inorganic carbon removed with nitrogen. The sample was mixed with persulfate buffer and irradiated in a UV destructor. Hydroxylamine was added and the sample entered into a dialyzer. The generated $\mathrm{CO}_{2}$ diffused through a gas-permeable silicone membrane. A weakly buffered phenolphthalein indicator solution was used as the recipient stream, and the color intensity of this solution decreased in proportion to the change in $\mathrm{pH}$ caused by the absorbed $\mathrm{CO}_{2}$ gas. The color was measured at $550 \mathrm{~nm}[27]$.

\subsubsection{Microbial Nitrogen (MBN)}

Microbial nitrogen (MBN) was determined using the chloroform fumigation-extraction (CFE) technique [28]. Soil samples with the addition of moisture (40\% WHC) were fumigated and extracted at a 1:10 (w/v) ratio with $0.01 \mathrm{M}$ calcium chloride solution. The same procedure was repeated with nonfumigated soil samples. Measurements of TSN were determined using a Skalar autoanalyzer by the same procedure as for TSN. Microbial $\mathrm{N}$ was calculated as the difference between fumigated and nonfumigated samples divided by the KEN value (extractable fraction of microbial biomass $\mathrm{N}$ ), 0.54 [22].

\subsection{5. $\mathrm{CO}_{2}$ Evolution (SR) and Microbial Biomass (MB)}

$\mathrm{CO}_{2}$ evolution (SR) and microbial biomass (MB) were determined using the MicroRespTM system [29], by measuring carbon dioxide evolution detected by dye plates - a colorimetric reaction using absorbent alkali with the ability to measure carbon dioxide evolution. Water was added to whole-soil samples in deep-well plates covered by dye plates in order to measure respiretion. Glucose was added to determine microbial biomass according to the SIR method [30].

Both $\mathrm{CO}_{2}$ evolution and microbial biomass were used for calculating the metabolic efficiency of the soil microbial population under environmental conditions. The coefficient $\left(\mathrm{qCO}_{2}\right)$ was calculated according to the fol- lowing equation [31]:

$$
\mathrm{qCO}_{2}=\mathrm{CO}_{2} \text { evolution } / \text { microbial biomass }
$$

\subsection{Statistical Analysis}

All data obtained in the study were subjected to statistical analysis of variance combined with post hoc Duncan's multiple range test (SPSS for Windows, version 10, SPSS Inc., Chicago IL) to evaluate differences between means. Treatment effects were tested by computing redundancy analysis (RDA) (Canoco version 4.5 for Windows, PRI Wageningen, the Netherlands) in order to evaluate its contribution to data variance. Differences at $P<0.05$ were considered statistically significant.

\subsection{Relative Percentage Calculation}

The data obtained in the current study reflected two main effects: the wildfire effect and the post-fire practice effect. The wildfire effect is much stronger than the logging effect [22] thus, in order to avoid the wildfire effect, the data were presented as a relative percentage calculated by the following equation:

$$
\text { (Post-fire practice/Unburned) } \times 100
$$

Statistical analysis was performed on the raw data before calculating the relative percentage, as specified above.

\section{RESULTS}

\section{Post-Fire Forest Management}

Soil moisture (SM) (Table 1) was higher in the unburned control area (UB: 12.9\%) than in the unlogged area (B-UL: 9.7\%), and lowest in the logged area (B-SL: $8.7 \%$ ) during the entire study period. This was also indicated by RDA analysis, where B-UL practice accounted for $33 \%$ of the SM variance (Table 2), as elucidated by the length and direction of the SM arrow in Figure 1. The differences in SM values between sampled areas were found mostly during winter and summer (Figure 2A), the two extreme moisture-related seasons. One and a half years after the initiation of logging, the differences between the two post-fire practices diminished and became non-significant (Figure 2A).

Organic carbon (OC) was higher in the UB and B-UL areas than in the B-SL areas throughout the study period (Table 1). However, RDA analysis showed a non-significant contribution of both practices (B-SL and B-UL) to the variance of organic $\mathrm{C}$ values (Table 2). It is also important to add that overall, OC exhibited minimal variation throughout the research period and was higher in the B-UL than in the B-SL areas only in autumn 2008 (Figure 2B), one year after salvage logging took place. 


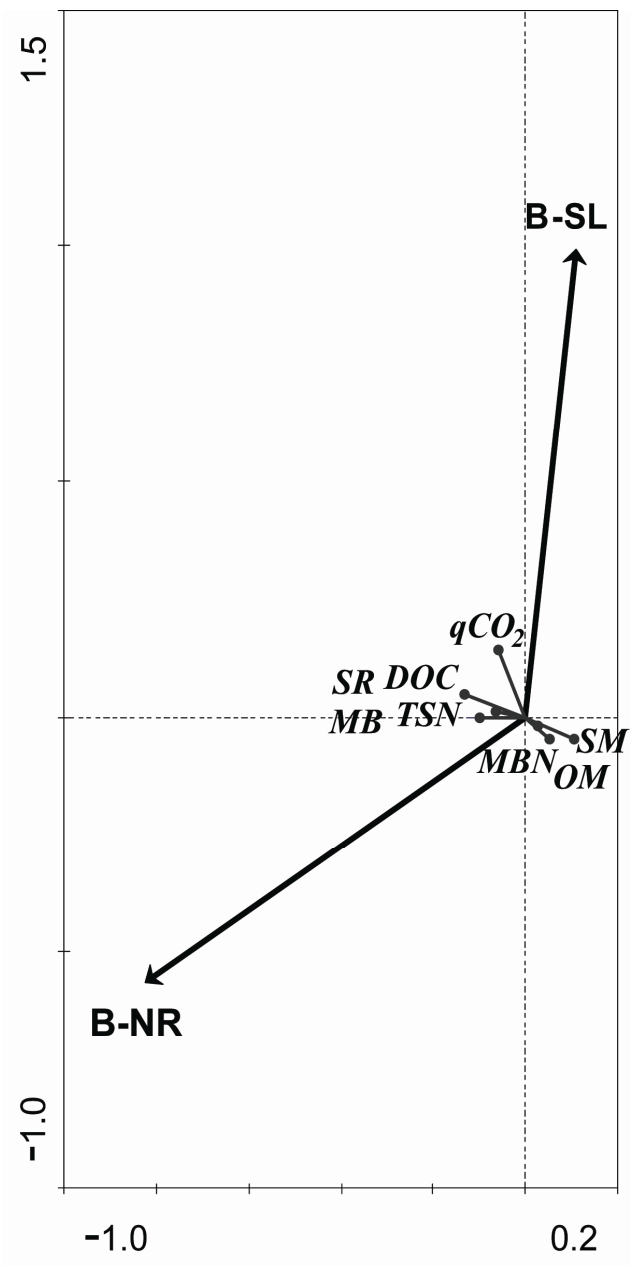

Figure 1. Redundancy discriminate analysis (RDA) of soil parameters between two post-fire forest practices, using 499 premutations. Soil parameters: $\mathrm{SM}=$ soil moisture $(\%)$; $\mathrm{OC}=$ organic carbon $(\%)$; TSN $=$ total soluble nitrogen $(\mathrm{mg} / \mathrm{kg}) ;$ DOC $=$ dissolved organic carbon $(\mathrm{mg} / \mathrm{kg}) ; \mathrm{SR}=$ soil respiration $\left(\mu \mathrm{gCO}_{2} / \mathrm{g}\right.$ soil $\left./ \mathrm{h}\right)$; $\mathrm{MB}=$ microbial biomass $(\mu \mathrm{gC} / \mathrm{g}$ soil $) ; \mathrm{qCO}_{2}=$ metabolic qoutient $\left(\mu \mathrm{gCO}_{2}-\mathrm{C} /\left(\mathrm{gC}_{\mathrm{mic}} \times \mathrm{h}\right) \times 10^{3}\right)$; $\mathrm{MBN}=$ microbial nitrogen $(\mathrm{mg} / \mathrm{kg})$. Post-fire practice: $\mathrm{B}-\mathrm{UL}=$ unlogged-natural regeneration; $\mathrm{B}-\mathrm{SL}=$ salvage logged.
When dissolved organic carbon (DOC) variations were examined throughout the study period, higher values were found in the B-SL and B-UL (60 and 60.1 $\mathrm{mg} / \mathrm{kg}$, respectively) than in the UB areas $(45.2 \mathrm{mg} / \mathrm{kg}$ ) (Table 1). This pattern was also recorded by RDA analysis, which showed non-significant contributions of both practices to the total explained variance of DOC (Table 2). In addition, the DOC arrow in Figure 1 is positioned in the middle between the B-SL and B-UL arrows, which indicates their equal influence. This equal influence could be the result of a turnover in the DOC patterning that occurred a year and a half after logging was initiated. This turnover was found when results were examined on a seasonal time scale (Figure 2(c)). From the time that logging was initiated until 1.5 years after initiation, higher DOC values (exhibited as relative percentage) were found in the B-SL area compared to the B-UL area during the summer and winter seasons. After this period, the pattern was reversed, and higher DOC values were found in the B-UL compared to the B-SL areas (Figure 2(c)) during spring and summer 2010.

Total soluble nitrogen (TSN) was lower in the UB plots than in the B-UL and B-SL plots, which had similar values, throughout the study period (Table 1). Such findings were mostly due to variation between the burned and the unburned plots that was related to wildfire effect and will not be discussed here. RDA analysis indicates a greater impact of B-UL practice on TSN values $(60 \%$ of its variance) compared to B-SL practice (30\%) (Table 2). However, the total variance explained by both practices was low, as indicated by the short length of the TSN arrow in Figure 1. When examined on a seasonal time scale (Figure 2(d)), differences in patterns between the two post-fire practices resembled those found in DOC but were not as strong. During winter 2008 (Figure 2(d)), higher TSN values were found in the B-SL (16.2 mg/kg) compared to the B-UL (9.9 mg/kg) areas. In spring and summer 2010, almost 3 years after logging was initiated, higher TSN values were found in the B-UL (4.8 mg/kg) compared to the B-SL (2.9 mg/kg) areas.

Table 1. Statistical analysis of differences between means of soil parameters at each of the sampling locations throughout the research period (autumn 2007-summer 2010).

\begin{tabular}{|c|c|c|c|c|c|c|c|c|}
\hline & SM & OC & TSN & DOC & SR & MBC & $\mathrm{qCO}_{2}$ & MBN \\
\hline UB & $12.9^{\mathrm{a}}$ & $2.68^{\mathrm{a}}$ & $2.12^{\mathrm{b}}$ & $45.26^{b}$ & $0.364^{\mathrm{b}}$ & $59.8^{\mathrm{c}}$ & $5.8^{\mathrm{c}}$ & $8.2^{\mathrm{a}}$ \\
\hline B-UL & $9.7^{\mathrm{b}}$ & $2.63^{\mathrm{a}}$ & $4.52^{\mathrm{a}}$ & $60.03^{\mathrm{a}}$ & $0.958^{\mathrm{a}}$ & $124.3^{\mathrm{a}}$ & $7.5^{\mathrm{b}}$ & $3.5^{\mathrm{b}}$ \\
\hline B-SL & $8.8^{\mathrm{c}}$ & $2.37^{\mathrm{b}}$ & $5.55^{\mathrm{a}}$ & $61.13^{\mathrm{a}}$ & $0.848^{\mathrm{a}}$ & $96.0^{\mathrm{b}}$ & $8.9^{\mathrm{a}}$ & $4.0^{\mathrm{b}}$ \\
\hline
\end{tabular}

Soil parameters: Abiotic: SM—soil moisture (\%); OC—organic carbon (\%); DOC—dissolved organic carbon (mg/kg); TSN—total soluble nitrogen $(\mathrm{mg} / \mathrm{kg})$; Biotic: $\mathrm{SR}$ - soil respiration $\left(\mu \mathrm{gCO}_{2} / \mathrm{g}\right.$ soil $\left./ \mathrm{h}\right) ; \mathrm{MB}$ - microbial biomass $(\mu \mathrm{gC} / \mathrm{g}$ soil $) ; \mathrm{qCO}_{2}-\mathrm{metabolic}_{\mathrm{qoutient}}\left(\mu \mathrm{gCO} 2^{-}\right.$ $\left.\mathrm{C} /\left(\mathrm{gC}_{\mathrm{mic}}{ }^{*} \mathrm{~h}\right){ }^{*} 10^{3}\right)$; and $\mathrm{MBN}$ - microbial nitrogen $(\mathrm{mg} / \mathrm{kg})$. Sampling locations: B-UL = unlogged-natural regeneration; B-SL = salvage logged; UB - unburned. ${ }^{\mathrm{a}-\mathrm{c}}$ : Different letters represent significant differences $(\mathrm{p}<0.05)$ between means for each separate parameter. 
Table 2. Summary of redundancy discriminante analysis (RDA) estimating the effect of two post-fire forest practices on soil parameters using 499 premutations.

\begin{tabular}{|c|c|c|c|c|c|c|c|c|c|c|c|c|}
\hline & & SM & & & OC & & & DOC & & & TSN & \\
\hline & F-ratio & p-value & Extra fit & F-ratio & p-value & Extra fit & F-ratio & p-value & Extra fit & F-ratio & p-value & Extra fit \\
\hline B-UL & 2.97 & NS & 0.0033 & $* * * * *$ & $* * * * *$ & $* * * * *$ & 0.53 & NS & 0.0006 & 5.75 & 0.022 & 0.0063 \\
\hline B-SL & 1.57 & NS & 0.0017 & 0.46 & NS & 0.0005 & 1.53 & NS & 0.0017 & 2.74 & NS & 0.003 \\
\hline \multirow[t]{3}{*}{ TVE } & & & 0.01 & & & 0 & & & 0 & & & 0.01 \\
\hline & & SR & & & MB & & & $\mathrm{qCO}_{2}$ & & & MBN & \\
\hline & F-ratio & p-value & Extra fit & F-ratio & p-value & Extra fit & F-ratio & p-value & Extra fit & F-ratio & p-value & Extra fit \\
\hline B-UL & 5.85 & 0.014 & 0.0064 & 10.23 & 0.002 & 0.0112 & 4.72 & 0.024 & 0.0051 & 8.64 & 0.004 & 0.0095 \\
\hline B-SL & 11.59 & 0.002 & 0.0126 & 4.76 & 0.016 & 0.0052 & 16.5 & 0.002 & 0.018 & 3.66 & 0.054 & 0.004 \\
\hline TVE & & & 0.02 & & & 0.02 & & & 0.02 & & & 0.01 \\
\hline
\end{tabular}

Soil parameters: Abiotic: SM—soil moisture (\%); OC—organic carbon (\%); DOC—dissolved organic carbon ( $\mathrm{mg} / \mathrm{kg})$; TSN—total soluble nitrogen (mg/kg). Biotic: SR—soil respiration $\left(\mu \mathrm{gCO}_{2} / \mathrm{g}\right.$ soil/ $\left./ \mathrm{h}\right) ; \mathrm{MB}$ - microbial biomass $(\mu \mathrm{gC} / \mathrm{g}$ soil $) ; \mathrm{qCO}_{2}$-metabolic qoutient $\left(\mu \mathrm{gCO} 2-\mathrm{C} /\left(\mathrm{gC}_{\text {mic }} \times \mathrm{h}\right) \times 10^{3}\right) ;$ and $\mathrm{MBN}-\mathrm{mi}_{-}$ crobial nitrogen $(\mathrm{mg} / \mathrm{kg})$. Sampling locations: B-UL — unlogged-natural regeneration; B-SL-salvage logged. TVE = total variance explained by post-fire forest practices. ${ }^{* * *}$ No additional variables can be added in order to improve the fit of the model. NS - not significant. Level of significance: $\mathrm{p}<0.05$.

(a)

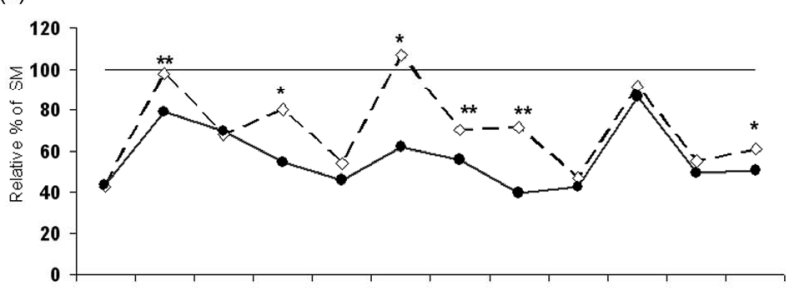

(c)

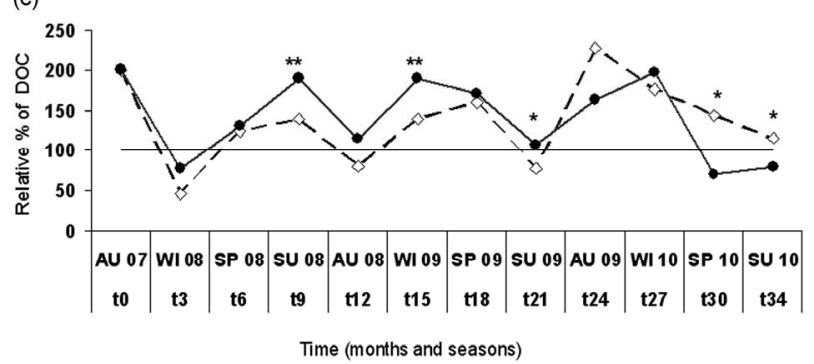

(b)

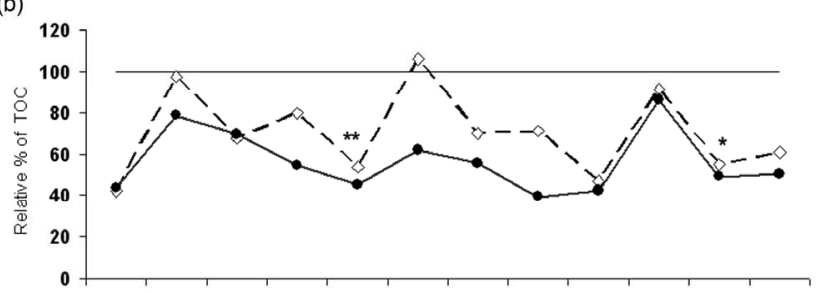

(d)

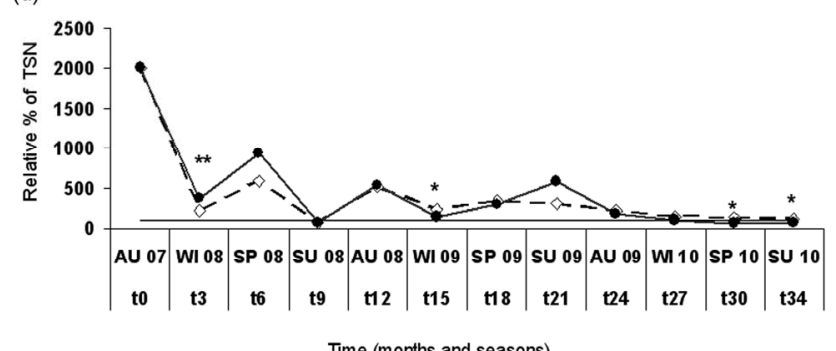

Figure 2. Changes in seasonal relative percentage of soil abiotic parameters: a) Soil moisture (SM) \%; b) Organic carbon (OC) \%; c) Dissolved organic carbon (DOC) $\mathrm{mg} / \mathrm{kg}$ soil; d) Total soluble nitrogen (TSN) $\mathrm{mg} / \mathrm{kg}$ soil; between the two post-fire forest practices: unlogged-natural regeneration (B-UL) $-\prec$; and salvage logged (B-SL) $-\bullet$ in relation to the control unburned state represented by black line. Asterisks represent significant differences between the two practices at the $\mathrm{p}<0.05$ level.

Soil respiration (SR) was higher in the B-UL and B-SL areas compared to the UB area, with no apparent effect of post-fire practices throughout the study period (Table 1). This pattern is related to wildfire effects on soil and will not be discussed this study. Although no apparent effect of post-fire practice was found, multivariable RDA analysis revealed that B-SL practice accounted for $63 \%$ of SR variance compared to $32 \%$ attributed to B-UL practice (Table 2). When examined on a time scale (Figure 3(a)), the differences between the two post-fire practices were detected even 3 years after logging. Higher SR values found in the B-UL practice compared to the B-SL practice were found almost consistently during all summer and autumn seasons (except summer 2009), whereas an opposite pattern was found during spring 2008 and 2009, and winter 2010 (Figure 3(a)).

Similarly, microbial biomass (MB) was higher in the burned areas (B-UL and B-SL) than in the unburned areas, with a significant effect of post-fire practice found as lower biomass in the B-SL ( $96 \mu \mathrm{gC} / \mathrm{g}$ soil) compared to 

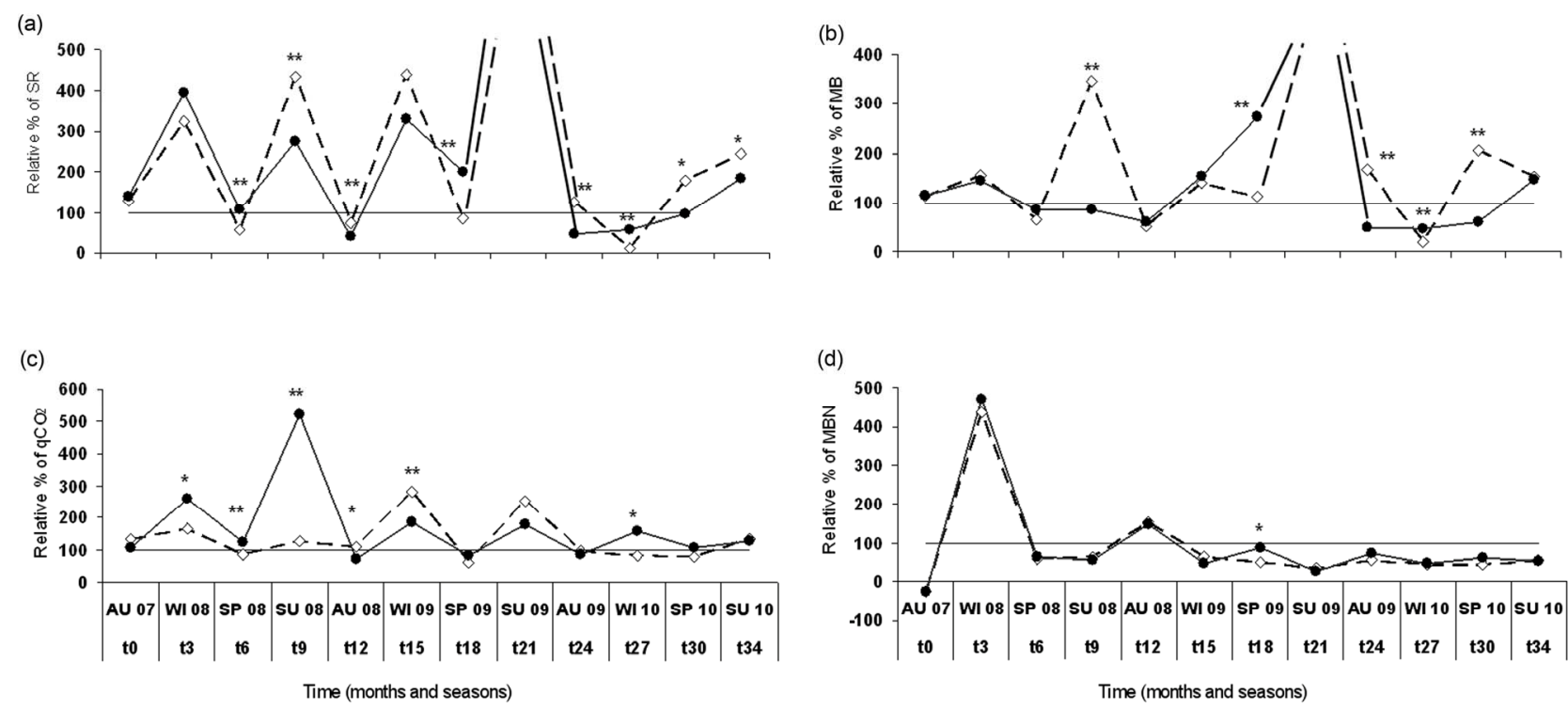

Figure 3. Changes in seasonal relative percentage of soil biotic parameters: a) Soil respiration (SR) $\mu \mathrm{gCO}_{2} / \mathrm{g}$ soil/h; b) Microbial biomass (MB) $\mu \mathrm{gC} / \mathrm{g}$ soil; c) Metabolic quotient $\left(\mathrm{qCO}_{2}\right) \mu \mathrm{gCO}_{2}-\mathrm{C} /\left(\mathrm{gC}_{\mathrm{mic}} \times \mathrm{h}\right) \times 10^{3}$; d) Microbial nitrogen $(\mathrm{MBN}) \mathrm{mg} / \mathrm{Kg}$ soil, between the two post-fire forest practices: unlogged-natural regeneration (B-UL) $-\prec$; and salvage logged (B-SL) $-\bullet-$ in relation to the control unburned state represented by black line. Asterisks represent significant differences between the two practices at the $p<0.05$ level. During summer 2009 values were 5 times higher for both soil respiration and microbial biomass and were left out so that the differences could be more obvious. No significant differences were found between the two post-fire forest practices at this time point.

the B-UL (124.3 $\mu \mathrm{gC} / \mathrm{g}$ soil) throughout the study period (Table 1). Accordingly, RDA analysis (Table 2) showed that $56 \%$ of MB variance was attributed to B-UL practice compared to $26 \%$ attributed to B-SL practice. Time scale analysis (Figure 3(b)) showed similar patterns to SR changes, where $\mathrm{MB}$ values were found to be higher in the B-UL areas compared to B-SL areas during summer 2008, autumn 2009, and spring 2010. An opposite pattern (B-SL > B-UL) was again found during spring 2009 and winter 2010 (Figure 3(b)).

The metabolic quotient index $\left(\mathrm{qCO}_{2}\right)$ is based on the ratio between SR and $\mathrm{MB}$, and indicates microbial metabolic efficiency [31]. High ratios indicate that the microbial community is under stress conditions. During the study period, a general pattern was found in which the highest $\mathrm{qCO}_{2}$ values were found in the B-SL > B-UL $>\mathrm{UB}$ areas (Table 1). In addition, multivariable RDA analysis showed a stronger connection of $\mathrm{qCO}_{2}$ values to B-SL practice (Figure 1), which accounted for $90 \%$ of its variance (Table 2). When examining the seasonaltemporal variation of $\mathrm{qCO}_{2}$ (Figure 3(c)), significantly higher values were found under salvage logging (B-SL) compared to unlogged practice (B-UL) during the first 9 months after logging (Figure 3(c)). This pattern was reversed during autumn 2008 and winter 2009, when $\mathrm{qCO}_{2}$ was higher in the B-UL than in the B-SL areas (Figure 3(c)).

Microbial nitrogen (MBN) was higher in the UB com- pared to both the B-UL and B-SL areas throughout the study period, with no apparent effect of post-fire practices (Table 1). These differences are the result of the wildfire effect and will not be discussed here. Similarly, RDA analysis showed that B-UL practice accounted for $95 \%$ of MBN variance (Table 2), which is also exhibited by the direction of the MBN arrow (Figure 1), however, the length of the arrow is small, indicating a minor influence. This was also the case when seasonal variation in MBN values were examined (Figure 3(d)), with no significant differences found at all sampling times between the two post-fire practices.

\section{DISCUSSION}

Post-fire forest management has received much attention recently [4-6,20] and as the frequency of forest wildfires increases, debate on the proper manner of forest rehabilitation continues. In this research, an attempt was made to examine the consequences of two different post-fire forest practices - human intervention by salvage logging (B-SL) and natural regeneration without logging (B-UL) - on the chemical and biological aspects of soil. Previous studies indicated the detrimental effect of logging on the soil system $[10,17,18]$ was usually related to soil erosion and compaction. However, there is a lack of data on the effect of salvage logging on a soil microbial community [4]. In the current study, some undesirable effects on soil chemical properties and microbial com- 
munities were also recorded, but in limited extent and time.

Soil moisture was one of the soil parameters strongly affected by the different post-fire forest practices in this study. It decreased significantly under salvage logging compared to the natural regeneration practice. These results are in agreement with the results of Greene et al. [4], who investigated the survival of Sphagnum in logged sites and found lower survival, indicative of drier conditions at these sites. Martínez-Sánchez et al. [32] also found a reduction in seedling height in logged plots and related it to water stress due to increased sunlight exposure. According to our results, seasonal variations and time influence the differences between the two practices. Most of the differences between logged and unlogged areas were observed during the two water-extreme seasons: summer (dry) and winter (moist). Furthermore, in the second year after logging, the differences between the two practices diminished and became non-significant. By that time, the logged areas were covered with dense vegetation of annuals and shrubs (personal observation of authors), which may increase soil water retention and reduce its loss. Increase in grass cover in clear-cut, harvested plots was also reported by Hannam et al. [33].

A positive impact of salvage-logging practice on soil organic carbon (OC) was observed in this study, with values remaining higher in logged areas compared to unlogged areas almost a year after logging. Fernández et al. [12] also found limited perturbation of logging operations on the soil organic layer and the upper centimeters of mineral soil. Also, according to Beghin et al. [5], salvage-logged, non-planted areas exhibit a dense herb layer that, in time, might compensate for organic matter losses. Parallel to the increase in organic carbon, an increase in dissolved organic-carbon (DOC) levels in logged areas was also recorded in this study. This increase was time-limited (lasted only until 1.5 years after logging), and then decreased to lower values than those found in the unlogged, naturally regenerated areas. Johnson and Curtis [34] explained the higher soil C levels in logged plots by the incorporation of slash into the mineral soil, especially in coniferous forests, which, when harvested, produce more soil $\mathrm{C}$ and $\mathrm{N}$ than hardwood. However, in this study, there was less impact of logging on total soluble nitrogen (TSN) levels, which increased in logged compared to unlogged areas only 3 months after logging, and then decreased to non-signifycant levels. Decreases in DOC and TSN levels in the salvaged-logged areas in this study could be a result of plant establishment in the exposed, unshaded areas of logged plots, which quickly utilize available $\mathrm{N}$ and $\mathrm{C}$, on the one hand, and increase organic matter on the other.

Measurements of soil microbial activity such as soil respiration and microbial biomass are indicative of pro- per soil function [35]. Since there are less data available on the salvage-logging effect on the soil microbial community [4], information is drawn from traditional forest-harvesting investigations [21,36,37]. Most of the harvesting operations cause major changes related to soil compaction [36]. Schnurr-Pütz et al. [38] indicated that soil compaction alters the structure and function of the microbial community and favors anaerobic prokaryotes. Siira-Pietikäinen et al. [39] reported that the decomposer community of coniferous-forest soils is resistant to initial environmental changes induced by forest harvesting. However, in the current study, a clear influence of salvage logging on soil microbial parameters was observed. Consequently, microbial activity-soil respiration and microbial biomass - was lower in the logged compared to unlogged, naturally regenerated areas.

These results correspond with the $18 \%$ decrease in microbial biomass carbon observed by Smith et al. [22] under harvest treatment. Moreover, the differences in microbial-activity measurements in this study were timelimited and extended only until a year after logging began. Higher microbial activity in the unlogged, naturally regenerated areas could be a result of the creation of new microsites by fallen trees and uprooted stumps that are more shaded and moist, with stabilizing microclimatic conditions [5]. The observed lower microbial activity in the logged areas found in this study was followed by an increase in metabolic quotient values $\left(\mathrm{qCO}_{2}\right)$ that lasted up to 9 months after logging and then decreased. Such higher $\mathrm{qCO}_{2}$ values are indicative of stressed environmental conditions that impact microbial activity [40]. Additionally, Smith et al. [22] reported a 25\% decrease of microbial $\mathrm{N}$ under harvest treatment, which could also be indicative of changes in microbial composition and function. However, in this study, no differences between microbial nitrogen in the two practices were found. The reason for this could be the rapid decrease in TSN levels in both the logged and unlogged, naturally regenerated areas found in this study.

\section{Post-Fire Practices: Recommendations}

Post-fire management activities such as salvage logging sometimes result in significant mortality of the managed areas, despite their restorative purposes, with timing of logging playing a critical role [41]. Fernández et al. [12] stated that postponement of harvesting by one year may lessen the negative impact of this practice on seedling recruitment. According to Izhaki and Ne'eman [42], this corresponds well with the time of pine-seed germination, which usually takes place in the post-fire wet season. By examining the response of the soil biotic and abiotic parameters to salvage-logging and naturalregeneration (no logging) post-fire forest practices, the results of the current study support the postponement of 
salvage-logging operation. As observed, most of the unfavorable changes in the logged areas were short-lived and diminished a year after logging operations. Taking into consideration that in this study logging operations were already postponed for a year after the wildfire, a longer time period of logging practice postponement should be considered. Moreover, postponement of logging operations will not completely eliminate negative consequences such as soil compaction, therefore, the means to diminish these consequences must be examined. For example, Greene et al. [4] suggested leaving a mosaic of logged and unlogged areas or belts, i.e., naturally regenerated sites around logged areas. In this way, naturally regenerated and logged sites will compensate each other and might ameliorate the damage caused by logging operation. With respect to soil function, we believe that such post-fire forest-management actions will be the most effective, however, this needs to be further investigated.

\section{ACKNOWLEDGEMENTS}

We wish to thank Mrs. Gineta Barness for technical assistance and Ms. Sharon Victor for useful comments. Special thanks to Dr. Marcelo Sternberg for constructive advice. This research is part of the Ph.D. thesis of Orit Ginzburg and was funded by the KKL organization. The funding source had no involvement in the study design, collection, analysis, and interpretation of data, in the writing of the paper, or in the decision to submit the paper for publication.

\section{REFERENCES}

[1] Flannigan, M.D., Bergeron, Y., Engelmark, O. and Wotton, B.M. (1998) Future wildfire in circumboreal forests in relation to global warming. Journal of Vegetation Science, 9, 469-476. doi:10.2307/3237261

[2] Li, C., Flannigan, M.D. and Corns, I.G.W. (2000) Influence of potential climate change on forest landscape dynamics of west-central Alberta. Canadian Journal of Forest Research, 30, 1905-1912. doi:10.1139/x00-118

[3] Nappi, A., Drapeau, P. and Savard, J.P.L. (2004) Salvage logging after wildfire in the boreal forest: Is it becoming a hot issue for wildlife? Forestry Chronicle, 80, 67-74.

[4] Greene, D.F., Gauthier, S., Noel, J., Rousseau, M. and Bergeron, Y. (2006) A field experiment to determine the effect of post-fire salvage on seedbeds and tree regeneration. Frontiers in Ecology and the Environment, 4, 69-74. doi:10.1890/1540-9295(2006)004[0069:AFETDT]2.0.CO ;2

[5] Beghin, R., Lingua, E., Garbarino, M., Lonati, M., Bovio, G., Motta, R. and Marzano, R. (2010) Pinus sylvestris forest regeneration under different post-fire restoration practices in the northwestern Italian Alps. Ecological Engineering, 36, 1365-1372. doi:10.1016/j.ecoleng.2010.06.014

[6] Lindenmayer, D.B. and Noss, R.F. (2006) Salvage log- ging, ecosystem processes, and biodiversity conservation. Conservation Biology, 20, 949-958.

[7] Lang, K.D., Schulte, L.A. and Guntenspergen, G.R. (2009) Windthrow and salvage logging in an old-growth hemlock-northern hardwoods forest. Forest Ecology and Management, 259, 56-64.

doi:10.1016/j.foreco.2009.09.042

[8] Beschta, R.L., Rhodes, J.J., Kauffman, J.B., Griesswell, R.E., Minshall, G.W., Karr, J.R., Perry, D.A., Hauer, E.R. and Frissell, C.A. (2004) Postfire management on forested public lands of the western United States. Conservation Biology, 18, 957-967. doi:10.1111/j.1523-1739.2004.00495.x

[9] Foster, D.R. and Orwig, D.A. (2006) Preemptive and salvage harvesting of New England forests: When doing nothing is a viable alternative. Conservation Biology, 20, 959-970. doi:10.1111/j.1523-1739.2006.00495.x

[10] McIver, J.D. and Starr, L. (2000) Environmental effects of postfire logging: literature review and annotated bibliography. PNW-GTR-486. Pacific Northwest, Research Station, Portland, Oregon.

[11] McIver, J.D. and Starr, L. (2001) A literature review on the environmental effects of postfire logging. Western Journal of Applied Forestry, 16, 159-168.

[12] Fernández, C., Vega, J.A., Fonturbel, T., Jiménez, E. and Pérez-Gorostiaga, P. (2008) Effects of wildfire, salvage logging and slash manipulation on Pinus pinaster Ait. recruitment in Orense (NW Spain). Forest Ecology and Management, 255, 1294-1304. doi:10.1016/j.foreco.2007.10.034

[13] Ne'eman, G. (1997) Regeneration of natural pine forest-Review of work done after the 1989 fire in Mount Carmel, Israel. International Journal of Wildland Fire, 7, 295-306. doi:10.1071/WF9970295

[14] Donato, D.C., Fontaine, J.B., Campbell, J.L., Robinson, W.D., Kauffman, J.B. and Law, B.E. (2006) Post-wildfire logging hinders regeneration and increases fire risk. Science, 311, 352-352. doi:10.1126/science. 1122855

[15] McIver, J.D. and Ottmar, R. (2007) Fuel mass and stand structure after post-fire logging of a severely burned ponderosa pine forest in northeastern Oregon. Forest Ecology and Management, 238, 268-279.

doi:10.1016/j.foreco.2006.10.021

[16] Thompson, J.R., Spies, T.A. and Ganio, L.M. (2007) Reburn severity in managed and unmanaged vegetation in a large wildfire. Proceedings of the National Academy of Sciences of the United States of America, 104, 1074310748. doi:10.1073/pnas.0700229104

[17] Rab, M.A. (1996) Soil physical and hydrological properties following logging and slash burning in the Eucalyptus regnans forest of southeastern Australia. Forest Ecology and Management, 84, 159-176. doi:10.1016/0378-1127(96)03740-1

[18] Karr, J.R., Rhodes, J.J., Minshall, G.W., Hauer, F.R., Beschta, R.L., Frissell, C.A. and Perry, D.A. (2004) The effects of postfire salvage logging on aquatic ecosystems in the American West. Bioscience, 54, 1029-1033. doi:10.1641/0006-3568(2004)054[1029:TEOPSL]2.0.CO;2 
[19] Beschta, R.L., Frissell, C.A., Gresswell, R., Hauer, E.R., Karr, J.R., Marshall, G.W., Perry, D.A. and Rhodes, J.J. (1995) Wildfire and salvage logging: Recommendations for ecologically sound post-fire salvage logging and other post-fire treatments on federal lands in the west. Pacific Rivers Council, Portland, Oregon.

[20] Cobb, T.P., Hannam, K.D., Kishchuk, B.E., Langor, D.W., Quideau, S.A. and Spence, J.R. (2010) Wood-feeding beetles and soil nutrient cycling in burned forests: Implications of post-fire salvage logging. Agricultural and Forest Entomology, 12, 9-18. doi:10.1111/j.1461-9563.2009.00440.x

[21] Chatterjee, A., Vance, G.F., Pendall, E. and Stahl, P.D. (2008) Timber harvesting alters soil carbon mineralization and microbial community structure in coniferous forests. Soil Biology and Biochemistry, 40, 1901-1907. doi:10.1016/j.soilbio.2008.03.018

[22] Smith, N.R., Kishchuk, B.E. and Mohn, W.W. (2008) Effects of wildfire and harvest disturbances on forest soil bacterial communities. Applied and Environmental Microbiology, 74, 224-216. doi:10.1128/AEM.01355-07

[23] Aström, M., Dynesius, M., Hylander, K. and Nilsson, C. (2007) Slope aspect modifies community responses to clear-cutting in Boreal forests. Ecology, 88, 749-758. doi:10.1890/06-0613

[24] Dan, J. and Koyumdjiski, H. (1979) The classification of Israel soils by the committee on soil classification in Israel. Special publication no. 137. Division of Scientific Publications, The Volcani Center, Bet Dagan, Israel.

[25] Steinberger, Y., Shmida, A. and Whitford, W.G. (1990) Decomposition along a rainfall gradient in the Judean Desert, Israel. Oecologia, 82, 322-324. doi:10.1007/BF00317478

[26] Rowell, D.L. (1994) Soil Science: Methods and Applications. Longman Group UK Ltd., London.

[27] Houba, V.J.G., Novozamsky, I., Vittenbogaard, J. and Van Der Lee, J.J. (1987) Automatic determination of total soluble nitrogen in soil extracts. Landwirtschaftliche Forschung, 40, 295-302.

[28] Brookes, P.C., Landman, A., Pruden, G. and Jenkinson, D.S. (1985) Chloroform fumigation and the release of soil nitrogen: A rapid direct extraction method to measure microbial biomass nitrogen in soil. Soil Biology and Biochemistry, 17, 837-842. doi:10.1016/0038-0717(85)90144-0

[29] Campbell, C.D., Chapman, S.J., Cameron, C.M., Davidson, M.S. and Potts, J.M. (2003) A rapid microtiter plate method to measure carbon dioxide evolved from carbon substrate amendments so as to determine the physiological profiles of soil microbial communities by using whole soil. Applied and Environmental Microbiology, 69, 35933599. doi:10.1128/AEM.69.6.3593-3599.2003

[30] Anderson, J.P.E. and Domsch, K.H. (1978) Physiological method for quantitative measurement of microbial biomass in soils. Soil Biology and Biochemistry, 10, 215221. doi:10.1016/0038-0717(78)90099-8

[31] Anderson, T.H. and Domsch, K.H. (1993) The metabolic quotient for $\mathrm{CO}_{2}\left(\mathrm{qCO}_{2}\right)$ as a specific activity parameter to assess the effects of environmental conditions, such as
$\mathrm{pH}$, on the microbial biomass of forest soils. Soil Biology and Biochemistry, 25, 393-395. doi:10.1016/0038-0717(93)90140-7

[32] Martinez-Sanchez, J.J., Ferrandis, P., de las Heras, J. and Herranz, J.M. (1999) Effect of burnt wood removal on the natural regeneration of Pinus halepensis after fire in a pine forest in Tus valley (SE Spain). Forest Ecology and Management, 123, 1-10. doi:10.1016/S0378-1127(99)00012-2

[33] Hannam, K.D., Quideau, S.A. and Kishchuk, B.E. (2006) Forest floor microbial communities in relation to stand composition and timber harvesting in northern Alberta. Soil Biology and Biochemistry, 38, 2565-2575. doi:10.1016/j.soilbio.2006.03.015

[34] Johnson, D.W. and Curtis, P.S. (2001) Effects of forest management on soil $\mathrm{C}$ and N storage: Meta analysis. Forest Ecology and Management, 140, 227-238.

[35] Sparling, G.P. (1997) Soil microbial biomass, activity and nutrient cycling as indicators of soil health. In: Pankhurst, C.E., Doube, B.M. and Gupta, V.V.S.R., Eds., Biological Indicators of Soil Health, CAB International, Wallingford, 97-120.

[36] Chanasyk, D.S., Whitson, I.R., Mapfumo, E., Burke, J.M. and Prepas, E.E. (2003) The impacts of forest harvest and wildfire on soils and hydrology in temperate forests: A baseline to develop hypotheses for the Boreal Plain. Journal of Environmental Engineering and Science, 2, S51-S62. doi:10.1139/s03-034

[37] Brooks, R.T. and Kyker-Snowman, T.D. (2008) Forest floor temperature and relative humidity following timber harvesting in southern New England, USA. Forest Ecology and Management, 254, 65-73. doi:10.1016/j.foreco.2007.07.028

[38] Schnurr-Pütz, S., Bååth, E., Guggenberger, G., Drake, H.L. and Küsel, K. (2006) Compaction of forest soil by logging machinery favours occurrence of prokaryotes. FEMS Microbiology Ecology, 58, 503-516. doi:10.1111/j.1574-6941.2006.00175.x

[39] Siira-Pietikainen, A., Pietikäinen, J., Fritze, H. and Haimi, J. (2001) Short-term responses of soil decomposer communities to forest management: Clear felling versus alternative forest harvesting methods. Canadian Journal of Forest Research, 31, 88-99. doi:10.1139/x00-148

[40] Insam, H. and Domsch, K.H. (1988) Relationship between soil organic carbon and microbial biomass on organic chronosequences of reclamation site. Microbial Ecology, 15, 177-188. doi:10.1007/BF02011711

[41] Keyser, T.L., Smith, F.W. and Shepperd, W.D. (2009) Short-term impact of post-fire salvage logging on regeneration, hazardous fuel accumulation, and understorey development in ponderosa pine forests of the Black Hills, SD, USA. International Journal of Wildland Fire, 18, 451-458. doi:10.1071/WF08004

[42] Izhaki, I. and Ne'eman, G. (2000) Soil seed banks in east Mediterranean pine forests. In: Ne'eman, G. and Trabaud, L., Eds., Ecology, Biogeography and Management of Pinus halepensis and P. brutia. Ecosystems in the Mediterranean Basin, Backhuys Publishers, Leiden, 167-182. 